\title{
The Possible Improving Effects of $\gamma$-Irradiated and/or Extruded Soy Flour on Hypercholesterolemic Rats
}

\author{
Refaat G. HAMZA', Safaa AFIFI' ${ }^{*}$, Abdel-Rahman B. ABDEL-GHAFFAR², Ibrahim H. BORAI ${ }^{2}$ \\ ${ }^{1}$ Department of Food Irradiation Research, National Centre for Radiation Research and Technology [NCRRT], Atomic Energy Authority, \\ 3 Ahmed El Zomor St., El Zohour District, 8 ${ }^{\text {th }}$ District, Nasr City, Cairo, Egypt; refaat.galal2009@yahoo.com ( ${ }^{*}$ corresponding author) \\ ${ }^{2}$ Department of Biochemistry, Faculty of Science, Ain Shams University Cairo, Egypt
}

\begin{abstract}
Hypercholesterolemia is serious conditions that can cause fatal complications without careful management. Among the dietary supplementation with functional food, soybeans possess variety of antioxidant compounds that may lower incidence of hypercholesterolemia and degenerative cardiovascular disease. Thus, the purpose of this study is to determine the effect of gammairradiated and/or extruded soy flour on hypercholesterolemic rats. Processing of soy flour by $\gamma$-irradiation and/or extrusion reduced the amount of antinutritional factors such as tannin and trypsin inhibitor and resulted in different changes in the total amino acids and fatty acid contents. The animals maintained on the HCD showed remarkable decrease in the level of HDL-C associated with significant increase in the values of serum total lipid, total cholesterol, triglyceride, LDL-C, vLDL-C and the risk ratio in addition to serum concentration of urea, creatinine and uric acid in comparison with those of the control group. However, dietary supplementation of raw and treated soy flour resulted in reduction in the bad changes induced by HCD in the above mentioned parameters. In conclusion, treated soy flour supplementation in diet of rats pointed out to its hypocholesterolemic effect and its ability to improve lipid profile and kidney function of hypercholesterolemic rats.
\end{abstract}

Keywords: extrusion, gamma-irradiation, hypercholesterolemia, soy flour

\section{Introduction}

Hypercholesterolemia is the presence of a high level of total cholesterol in the bloodstream (Barbana et al., 2010) and it is closely associated with obesity, diabetes mellitus, and several other metabolic syndromes (Aleisa et al., 2013). Also, it seems to be an important risk factor accounting for severe atherosclerotic diseases (Augusti $e t$ al., 2012).

Several studies indicated that soybean (Glycine max (L.) Merrill) is an effective dietary component and contains many bioactive components such as soy protein and soy isoflavones that can improve lipid profiles and reduce risk factors for chronic diseases like hypercholesterolemia and cardiovascular disease (Llaneza et al., 2011).

Moreover, soybean contains several antinutritional factors, which could limit their consumption such as trypsin inhibitors (TI) and tannin content (Gu et al., 2010) and removal of undesirable components is essential to improve the nutritional quality of soy. Various conventional and simple processing methods have been used such as gammairradiation (Dixit et al., 2011) and extrusion (Frias et al., 2011) in order to inactivate or reduce the antinutritional substances.

Therefore, the objective of the present study was oriented to the use of $\gamma$-irradiation and/or extrusion for in- activation or removal of certain antinutritional factors as well as to study the biochemical effect of $\gamma$-irradiated and/ or extruded soy flour on lipid profile in hypercholesterolemic rats.

\section{Materials and methods}

\section{Material}

Freshly dried soybean seeds were obtained from the Agriculture Research Institute, Ministry of Agriculture and Land Reclamation, Giza, Egypt. Seeds were sorted by discarding damaged and immature ones. They were stored in air-tight containers at room temperature $\left(25 \pm 1{ }^{\circ} \mathrm{C}\right)$ prior to further use.

\section{Processing of soy bean seeds}

\section{a-Gamma irradiation treatment}

Soybean seeds were packed in polyethylene bags, and sealed by heat. Each bag contained about $500 \mathrm{~g}$ for gamma irradiation treatment. They were subjected at ambient temperature to gamma irradiation from 60Co source at the National Center for Radiation Research and Technology (NCRRT) - Nasr City, Cairo, Egypt. The facility used was the Indian Gamma Chamber 400 A, 60 Co facility. The doses applied were 5, $10 \mathrm{kGy}$, delivered at a dose rate 
of $4.75 \mathrm{kGy} / \mathrm{h}$ as calibrated using small pieces of the radio chromic film (McLaughlin et al., 1985), at the time of experimentation.

\section{$b$ - Heat processing (Extrusion)}

The whole soybean seeds were cleaned, dehulled and then extruded by single screw extruder with three zones (At the soy processing unit, food Technology Research Institute, Agriculture Research Center, Giza, Egypt). The heat treatment rise gradually through extruder zones for short time (Wijeratne and Nelson, 1993).

\section{c-Combination of $\gamma$-irradiation and extrusion}

Soybean seeds were subjected to gamma irradiation at dose levels of ( 5 and $10 \mathrm{kGy}$ ) then followed by heat processing.

\section{Determination of antinutritional factors}

Tannins content were measured by using the vanillin$\mathrm{HCl}$ method (Burns, 1971). The trypsin inhibitors were determined according to (Hamerstrand $e t$ al., 1981) using benzoyl-DL-arginine-p-nitroanilide (BAPA) as substrate.

\section{Biological study Diet}

The raw and processed soy flour mixed with the other feed ingredients. Vitamin-mineral mixture was prepared by mixing analytically pure vitamin compounds with mineral salts and kept at $4^{\circ} \mathrm{C}$ until used. The dietary mixture was freshly prepared every week. Control group received a basic diet ( $20 \%$ casein, $10 \%$ soybean oil, $5 \%$ cellulose, $4 \%$ mineral mix, $2 \%$ vitamin mix, $6 \%$ sucrose, and $53 \%$ cornstarch), hypercholestrolemic group received the same diets supplemented with $1 \%$ cholesterol, $15 \%$ sheep tail fat and $0.25 \%$ cholic acid (Rossi, 2000), while other groups received hypercholesterolemic diet containing raw and treated soy flour obtained in Tab. 1.

Tab. 1. Composition of the experimental diets ( $\mathrm{g} \mathrm{kg}-1 \mathrm{diet})$

\begin{tabular}{|cc|}
\hline Ingredients $(\mathrm{g} / \mathrm{kg})^{*}$ & High Cholesterol Diet \\
\hline Soy flour & \\
\hline oil & 465 \\
\hline Cornstarch & ---- \\
\hline Sucrose & 231.5 \\
\hline Cellulose & 60 \\
\hline Vitamin mix ${ }^{* *}$ & 21 \\
\hline Mineral mix ${ }^{* *}$ & 20 \\
\hline Cholic acid & 40 \\
\hline Cholesterol & 2.5 \\
\hline Sheep tail fat & 10 \\
\hline Total & 150 \\
\hline
\end{tabular}

* treated soy flour.

**The mixture provides the following: Vit. A, 2000 IU; Vit. D, 200 IU; Vit.E, 10 IU; Menadione, O.5; Choline, 200; Aminobenzoic Acid, 10; Inositol, 10; Niacin, 4; Ca D-Pantothenate, 4; Riboflavin, 0.8; Thiamine. $\mathrm{HCl}, 0.5$; Pyridoxine- $\mathrm{HCl}, 0.5$; Folic acid, 0.2; Biotin, 0.04; Vit. B12, 0.003; Glucose, to make 1000g.

\section{Animals}

The experiments were conducted on male albino senile rats $(130-150 \mathrm{~g})$. The animals were housed under conditions of controlled temperature $\left(30 \pm 2{ }^{\circ} \mathrm{C}\right)$ with natural light.

The animals were randomly divided into 8 groups, each consisted of 10 rats.

- Group I: Fed on the basal diet for 10 weeks and considered as control group.

- Group II: Fed on hypercholesterolemic diet for 10 weeks and considered as a positive control group.

- Group III: Fed on hypercholesterolemic diet containing raw soybean flour for 10 weeks and considered as a treated control group.

- Group IV: Fed on hypercholesterolemic diet with $\gamma$-irradiated soybean flour ( $5 \mathrm{kGy}$ ) for 10 weeks.

- Group V: Fed on hypercholesterolemic diet with $\gamma$-irradiated soybean flour (10 kGy) for 10 weeks.

- Group VI: Fed on hypercholesterolemic diet with extruded soybean flour for 10 weeks.

- Group VII: Fed on hypercholesterolemia diet with $\gamma$ - irradiated (5 kGy) and extruded soybean flour for 10 weeks.

- Group VIII: Fed on hypercholesterolemic diet with $\gamma$-irradiated (10 kGy) and extruded soy flour for 10 weeks.

At the end of the experimental period, the rats in each group were fasted overnight, anaesthetized with diethyl ether and sacrificed. Blood samples were collected by heart puncture, allowed to coagulate and centrifuged to obtain serum for biochemical analysis.

\section{Biochemical Analysis}

Total lipids (TL), Total cholesterol (TC), triglycerides (TG) and high-density lipoprotein-cholesterol (HDL-C) were determined according to the procedure described by Zollner and Krisch (1962), Richmond (1973), Fassati and Prencipe (1982) and Lopez-Virella et al. (1977). Low-density lipoprotein-cholesterol, very Low-density lipoprotein-cholesterol and risk ratio were evaluated according to Friedewald et al. (1972) formulas, respectively by the following equations: LDL-C $(\mathrm{mg} / \mathrm{dl})=\mathrm{TC}$ - $(\mathrm{TG} / 5+\mathrm{HDL}-\mathrm{C}), \mathrm{vLDL}(\mathrm{mg} / \mathrm{dl})=\mathrm{TG} / 5$ and the risk ratio $=\mathrm{TC} / \mathrm{HDL}$. Serum uric acid determination was carried out according to Young (1990), serum creatinine determination was carried out according to Giorgio (1974) and urea was determined by Crouch and Batton (1977).

\section{Statistical analysis}

Statistical analyses were performed using computer program Statistical Packages for Social Science (SPSS, 1998), and values compared with each other using suitable tests. 
422

\section{Results and discussion}

A significant reduction was noticed in the values of tannin content and trypsin inhibitor (TI) by processing of raw flour and the highest reduction was observed in irradiated (10 KGy) +extruded soy flour (Fig. 1).

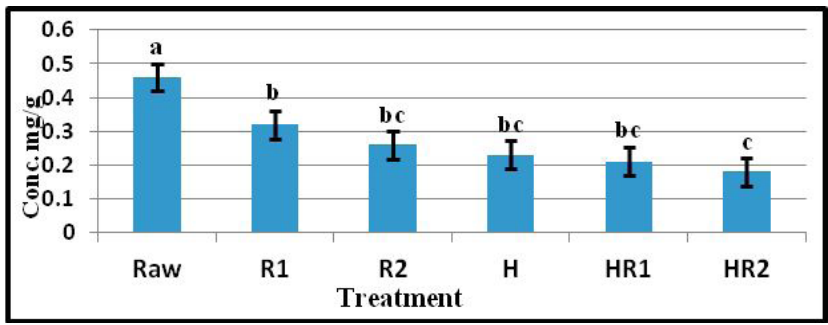

Fig. 1(a). Effects of $\gamma$-irradiation and/or extrusion on tannic acid of soy flour. a,b,c, Means within same column followed by different letters are significantly different at $(\mathrm{P}<0.05)$, Values are means of three replicates $( \pm \mathrm{SE})$. Raw $\rightarrow$ raw soy flour, $\mathrm{R} 1 \rightarrow$ irradiated at dose $5 \mathrm{kGy}, \mathrm{R} 2 \rightarrow$ irradiated at dose $10 \mathrm{kGy}, \mathrm{H} \rightarrow$ extruded, HR $1 \rightarrow$ irradiated $(5 \mathrm{KGY})+$ Extruded, HR2 $\rightarrow$ irradiated $(10 \mathrm{KGY})+$ Extruded

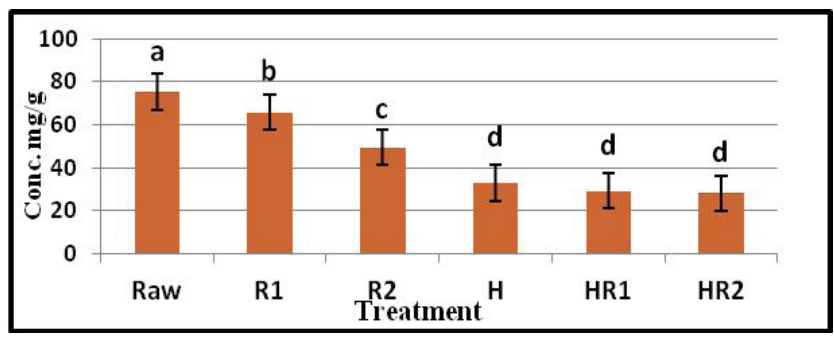

Fig. 1(b). Effects of $\gamma$-irradiation and/or extrusion on trypsin inhibitor of soy flour. a,b,c, means within same column followed by different letters are significantly different at $(\mathrm{P}<0.05)$, Values are means of three replicates $( \pm S E)$. Raw $\rightarrow$ raw soy flour, $\mathrm{R} 1 \rightarrow$ irradiated at dose $5 \mathrm{kGy}, \mathrm{R} 2 \rightarrow$ irradiated at dose $10 \mathrm{kGy}, \mathrm{H} \rightarrow$ extruded, HR $1 \rightarrow$ irradiated $(5 \mathrm{KGY})+$ Extruded, HR2 $\rightarrow$ irradiated $(10 \mathrm{KGY})+$ Extruded

The animals maintained on the HCD showed significant high values of some lipid contents associated with remarkable decrease in the level of HDL-C in comparison with those of the control group. However, dietary supplementation of raw and treated soy flour resulted in reduction in the bad changes induced by HCD in the above mentioned parameters.

Rats received daily diet rich in cholesterol had an obvious increase in the serum concentration of urea, creatinine and uric acid compared to the control group. On the other hand, supplementation of HCD with raw and processed soy flour enhanced a significant reduction in the serum level of these constituents.

High dietary cholesterol intake is known risk factor for the development of steatohepatitis (non-alcoholic fatty liver disease), atherosclerosis in humans and animals
(Townsend et al., 2008). Soybeans (Glycine max) is a species of legumes that becoming an important economic crop as a major source of protein, energy, polyunsaturated fats, fiber, vitamins, minerals, and other nutrients, for both humans and animals (Rettberg et al., 2011).

In this work, $\gamma$-irradiation treatment and/or extrusion reduced the trypsin inhibitor activity (TIA) of soy bean and the maximum reduction was observed in case of irradiation $(10 \mathrm{kGy})+$ extrusion. Inactivation of trypsin inhibitor in irradiated samples could be attributed to the destruction of disulphide (-S-S-) groups (Tresina and Mohan, 2012). Abu-Tarboush (1998) found reduction of $34.9 \%$ on the trypsin inhibitory activity in soybean flour radiated with $10 \mathrm{kGy}$. The author attributed this reduction to the breakage of the trypsin Inhibitory structure with the radiation treatment. Thermal treatment had been reported to be a valuable process for the inactivation of TIA. The reduction in TIA following extrusion by up to $90 \%$ was reported in the literature for other foods particularly mungbean, cowpea and blends with other crops (Alonso et al., 2000a, 2000b).

Also, the results revealed a significant reduction in tannins as a result of gamma irradiation. Similar results were reported by Musa et al. (2010). The reduction in tannin content is very favorable since this anti-nutritional factor has the capacity for decreasing protein digestibility. The reduction is probably due to chemical degradation by the action of the hydroxyl and superoxide anion radicals generated by the irradiation (Musa et al., 2010). The extrusion processing in this study resulted in decrease in tannin content. Alonso et al. (2000b) studied the effects of extrusion and conventional processing methods on protein and antinutritional factors in peas and they found varietal changes in their tannin contents, and extrusion was most effective in reducing tannins than the other processes. In addition, El-hady and Habiba (2003) have reported significant reduction in tannin content after extruding legume seeds at different moisture contents.

Derangements in cholesterol metabolism have been associated with the etiology of most human diseases. It is widely reported that high dietary cholesterol intake occasioned by a defect in cholesterol transportation, biosynthesis or catabolism is a risk factor in coronary heart disease (CHD) and atherosclerosis (30). Hence, prevention of hypercholesterolemia will be a positive step in the right direction for the management and treatment of cardiovascular diseases. The results of the present investigation show that rats fed with cholesterol rich diet developed hypercholesterolemia with a significant elevation in serum total lipid, total cholesterol (TC), triglycerides and low density lipoprotein (LDL-C) while there was a significant decrease in the HDL-C compared to control (Tab. 2). These results are in agreement with earlier reports on dietary hyperlipidemia (Abdulazeez, 2011) and hypercholesterolemia (Olorunnisola et al., 2012). Moreover, prolonged administration of a high-cholesterol diet 
Tab. 2. Effects of dietary supplementation by raw and treated soy flour to HC rats on lipid profile

\begin{tabular}{|c|c|c|c|c|c|c|c|}
\hline $\begin{array}{l}\text { Animal } \\
\text { groups }\end{array}$ & $\mathrm{TL}(\mathrm{mg} / \mathrm{dl})$ & $\begin{array}{c}\mathrm{TC} \\
(\mathrm{mg} / \mathrm{dl})\end{array}$ & $\begin{array}{c}\mathrm{TG} \\
(\mathrm{mg} / \mathrm{dl})\end{array}$ & $\begin{array}{l}\text { HDL-C } \\
(\mathrm{mg} / \mathrm{dl})\end{array}$ & $\begin{array}{l}\text { LDL-C } \\
(\mathrm{mg} / \mathrm{dl})\end{array}$ & $\begin{array}{l}\text { LDL-C } \\
(\mathrm{mg} / \mathrm{dl})\end{array}$ & Risk ratio \\
\hline Control & $\begin{array}{c}499.634 \\
\pm 12.774^{\mathrm{h}}\end{array}$ & $\begin{array}{l}138.352 \\
\pm 0.579^{h}\end{array}$ & $\begin{array}{l}105.469 \\
\pm 1.976^{g}\end{array}$ & $\begin{array}{c}48.878 \\
\pm 0.582^{\mathrm{a}}\end{array}$ & $\begin{array}{c}68.238 \\
\pm 0.398^{\mathrm{h}}\end{array}$ & $\begin{array}{l}21.094 \\
\pm 0.396^{\mathrm{g}}\end{array}$ & $\begin{array}{c}2.845 \\
\pm 0.023^{g}\end{array}$ \\
\hline $\mathrm{HCD}$ & $\begin{array}{l}1310.75 \\
\pm 5.689^{\mathrm{a}}\end{array}$ & $\begin{array}{l}295.779 \\
\pm 1.867^{\mathrm{a}}\end{array}$ & $\begin{array}{l}202.128 \\
\pm 2.056^{\mathrm{a}}\end{array}$ & $\begin{array}{c}27.74 \\
\pm 1.004^{\mathrm{f}}\end{array}$ & $\begin{array}{l}227.614 \\
\pm 1.512^{\mathrm{a}}\end{array}$ & $\begin{array}{c}40.426 \\
\pm 0.4112^{\mathrm{a}}\end{array}$ & $\begin{array}{c}10.724 \\
\pm 0.356^{\mathrm{a}}\end{array}$ \\
\hline Raw & $\begin{array}{l}993.590 \\
\pm 2.493^{\mathrm{b}}\end{array}$ & $\begin{array}{l}237.508 \\
\pm 1.849^{\mathrm{b}}\end{array}$ & $\begin{array}{l}162.810 \\
\pm 1.750^{\mathrm{b}}\end{array}$ & $\begin{array}{l}32.781 \\
\pm 0.673^{\mathrm{c}}\end{array}$ & $\begin{array}{l}172.165 \\
\pm 1.111^{\mathrm{b}}\end{array}$ & $\begin{array}{c}32.561 \\
\pm 0.348^{b}\end{array}$ & $\begin{array}{c}7.253 \\
\pm 0.111^{\mathrm{b}}\end{array}$ \\
\hline $\mathrm{R} 1$ & $\begin{array}{l}778.121 \\
\pm 3.755^{\mathrm{d}}\end{array}$ & $\begin{array}{l}200.662 \\
\pm 2.738^{d}\end{array}$ & $\begin{array}{l}139.291 \\
\pm 2.211^{\mathrm{d}}\end{array}$ & $\begin{array}{l}35.488 \\
\pm 0.885^{\mathrm{d}}\end{array}$ & $\begin{array}{l}137.317 \\
\pm 2.295^{\mathrm{d}}\end{array}$ & $\begin{array}{l}27.858 \\
\pm 0.443^{d}\end{array}$ & $\begin{array}{c}5.662 \\
\pm 0.123^{c}\end{array}$ \\
\hline R2 & $\begin{array}{l}754.782 \\
\pm 3.024^{\mathrm{c}}\end{array}$ & $\begin{array}{l}192.552 \\
\pm 1.480^{c}\end{array}$ & $\begin{array}{l}134.191 \\
\pm 1.649^{\circ}\end{array}$ & $\begin{array}{l}38.567 \\
\pm 0.959^{\circ}\end{array}$ & $\begin{array}{l}127.147 \\
\pm 0.356^{\mathrm{c}}\end{array}$ & $\begin{array}{l}26.838 \\
\pm 0.33^{\mathrm{c}}\end{array}$ & $\begin{array}{l}5.001 \\
\pm 0.09^{\mathrm{d}}\end{array}$ \\
\hline $\mathrm{H}$ & $\begin{array}{l}840.857 \\
\pm 1.310^{c}\end{array}$ & $\begin{array}{c}210.840 \\
\pm 3.617\end{array}$ & $\begin{array}{l}146.615 \\
\pm 2.019^{c}\end{array}$ & $\begin{array}{c}34.467 \\
\pm 1.054^{\mathrm{de}}\end{array}$ & $\begin{array}{l}147.050 \\
\pm 2.708^{\mathrm{c}}\end{array}$ & $\begin{array}{l}29.323 \\
\pm 0.403^{\mathrm{c}}\end{array}$ & $\begin{array}{c}5.907 \\
\pm 0.141^{\mathrm{c}}\end{array}$ \\
\hline HR1 & $\begin{array}{l}614.518 \\
\pm 2.827^{\mathrm{f}}\end{array}$ & $\begin{array}{l}179.385 \\
\pm 1.558^{\mathrm{f}}\end{array}$ & $\begin{array}{l}130.615 \\
\pm 1.038^{\mathrm{c}}\end{array}$ & $\begin{array}{c}40.508 \\
\pm 1.079^{\mathrm{bc}}\end{array}$ & $\begin{array}{l}112.754 \\
\pm 0.713^{\mathrm{f}}\end{array}$ & $\begin{array}{l}26.123 \\
\pm 0.207^{\mathrm{c}}\end{array}$ & $\begin{array}{l}4.440 \\
\pm 0.087^{\mathrm{c}}\end{array}$ \\
\hline HR2 & $\begin{array}{l}563.367 \\
\pm 2.253^{\mathrm{g}}\end{array}$ & $\begin{array}{l}166.256 \\
\pm 1.693^{g}\end{array}$ & $\begin{array}{l}121.65 \\
\pm 1.108^{\mathrm{f}}\end{array}$ & $\begin{array}{c}42.374 \\
\pm 0.819^{\mathrm{b}}\end{array}$ & $\begin{array}{l}99.545 \\
\pm 1.429^{g}\end{array}$ & $\begin{array}{l}24.337 \\
\pm 0.221^{\mathrm{f}}\end{array}$ & $\begin{array}{c}3.926 \\
\pm 0.072^{\mathrm{f}}\end{array}$ \\
\hline
\end{tabular}

${ }^{a, b}$, Means within same column followed by different letters are significantly different at $(\mathrm{P}<0.05)$, Values are means of three replicates $( \pm \mathrm{SE})$. Raw $\rightarrow$ raw soy flour, $\mathrm{R} 1 \rightarrow$ irradiated at dose $5 \mathrm{kGy}, \mathrm{R} 2 \rightarrow$ irradiated at dose $10 \mathrm{kGy}, \mathrm{H} \rightarrow$ extruded, $\mathrm{HR} 1 \rightarrow$ irradiated $(5 \mathrm{KGY})+$ Extruded, HR2 $\rightarrow$ irradiated $(10 \mathrm{KGY})+$ Extruded.

Tab. 3. Effects of dietary supplementation by raw and treated soy flour to hypercholesterolemic rats on kidney function

\begin{tabular}{|c|c|c|c|}
\hline Animal groups & $\begin{array}{c}\text { Urea } \\
(\mathrm{mg} / \mathrm{dl})\end{array}$ & Uric acid (mg/dl) & Creatinine $(\mathrm{mg} / \mathrm{dl})$ \\
\hline Control & $\begin{array}{c}41.479 \\
\pm 0.289 \mathrm{~g}\end{array}$ & $\begin{array}{c}5.355 \\
\pm 0.082^{\mathrm{h}}\end{array}$ & $\begin{array}{c}1.186 \\
\pm 0.032^{\mathrm{f}}\end{array}$ \\
\hline $\mathrm{HCD}$ & $\begin{array}{l}59.633 \\
\pm 0.311^{\mathrm{a}}\end{array}$ & $\begin{array}{c}8.936 \\
\pm 0.082^{\mathrm{a}}\end{array}$ & $\begin{array}{c}2.069 \\
\pm 0.062^{\mathrm{a}}\end{array}$ \\
\hline Raw & $\begin{array}{c}50.668 \\
\pm 0.471^{b}\end{array}$ & $\begin{array}{c}7.078 \\
\pm 0.047^{\mathrm{b}}\end{array}$ & $\begin{array}{c}1.529 \\
\pm 0.028^{b}\end{array}$ \\
\hline $\mathrm{R} 1$ & $\begin{array}{c}45.810 \\
\pm 0.337^{\mathrm{d}}\end{array}$ & $\begin{array}{c}6.491 \\
\pm 0.023^{d}\end{array}$ & $\begin{array}{c}1.331 \\
\pm 0.021^{\mathrm{cd}}\end{array}$ \\
\hline $\mathrm{R} 2$ & $\begin{array}{c}45.115 \\
\pm 0.194^{\mathrm{dc}}\end{array}$ & $\begin{array}{c}6.22 \\
\pm 0.016^{\mathrm{c}}\end{array}$ & $\begin{array}{c}1.301 \\
\pm 0.018^{\mathrm{de}}\end{array}$ \\
\hline $\mathrm{H}$ & $\begin{array}{c}47.904 \\
\pm 0.319^{c}\end{array}$ & $\begin{array}{c}6.629 \\
\pm 0.021^{c}\end{array}$ & $\begin{array}{c}1.40 \\
\pm 0.018^{c}\end{array}$ \\
\hline HR1 & $\begin{array}{r}44.672 \\
\pm 0.383^{c}\end{array}$ & $\begin{array}{c}5.720 \\
\pm 0.022^{f}\end{array}$ & $\begin{array}{c}1.268 \\
\pm 0.015^{\text {def }}\end{array}$ \\
\hline $\mathrm{HR} 2$ & $\begin{array}{l}43.218 \\
\pm 0.305^{f}\end{array}$ & $\begin{array}{c}5.5337 \\
\pm 0.019^{\mathrm{g}}\end{array}$ & $\begin{array}{c}1.202 \\
\pm 0.016^{\text {ef }}\end{array}$ \\
\hline
\end{tabular}

a,b,c, Means within same column followed by different letters are significantly different at $(\mathrm{P}<0.05)$, Values are means of three replicates $( \pm \mathrm{SE})$. Raw $\rightarrow$ raw soy flour, $\mathrm{R} 1 \rightarrow$ irradiated at dose $5 \mathrm{kGy}, \mathrm{R} 2 \rightarrow$ irradiated at dose $10 \mathrm{kGy}, \mathrm{H} \rightarrow$ extruded, HR $1 \rightarrow$ irradiated $(5 K G Y)+$ Extruded, HR2 $\rightarrow$ irradiated $(10 K G Y)+$ Extruded. 
424

to animals will accelerate the synthesis of TG, inhibit the metabolism of fatty acids and diminish the secretion of TG from the liver to blood by decreasing the $\beta$-oxidation of fatty acids. It leads to the accumulation of excess TG in the liver and the content of TC in mouse serum increased significantly, compared with the normal control group rats (Feng et al., 2011).

On the other hand, the present study showed that consumption of HCD containing either raw or processed soy flour have benefit effects on lipid profile which lowered the levels of total lipids, cholesterol, triglycerides and low density lipoprotein (LDL), and significantly increased HDL-C concentration compared to HCD fed rats. Moreover, results of rats fed HCD with $\gamma$-irradiated (10kGy) +extruded soy flour provided marked effect on serum lipid and lipoprotein concentrations than the other groups. That refers to the both effect of gamma irradiation and extrusion which cause increase in the contents of essential amino acids and phenolic compound as well as removal of large portion of the antinutritional contents.

The mechanism for the cholesterol lowering effects of soy protein is that peptides resulting from the digestion of soy protein up regulate hepatic LDL receptors (Manzoni $e t$ al., 2003). Isoflavones may work by making the liver more efficient to remove the bad cholesterol from the blood by increasing LDL-receptor densities in the liver (Baum et al., 1998). In addition, Lee et al. (2012) reported that soy flour decreased low density lipoprotein-cholesterol and increased high density lipoprotein-cholesterol. High density lipoprotein (HDL) may enhance the removal of cholesterol from peripheral tissue to the liver for catabolism and excretion.

As a result of HCD intake in this study, urea, createinine and uric acid concentrations were increased in the serum of hypercholesterolemic rats (Tab. 3). The elevated urea level in hypercholesterolemic rats is likely due to increased amino acid catabolism, impaired kidney function or liver damage (Pedraza et al., 2004). Yang et al. (2012) observed an increased serum creatinine levels and induced severe renal tubular necrosis in rats fed the high-cholesterol diet for 8 weeks but not in rats fed the normal diet or high-cholesterol diet for 2 weeks. The authors concluded that long-term hypercholesterolemia appeared to be a risk factor for contrast-induced acute kidney injury (CI-AKI), which might be associated with disorders in intrarenal prostaglandins and abnormalities in renal nitric oxide system induced by lipid peroxidation.

However, supplementation of soy flour (raw or processed) to the HCD induced reduction of urea, createinine and uric acid levels and that could be attributed to phenolics and isoflavones scavenge properties and prevention of renal tissue damages via protecting lipids structures in renal cells from the peroxidation by ROS induced by hypercholestrolemic diet. Similarly, Khan and Sultana (2004) observed a marked reduction in the levels of blood urea nitrogen and serum createinine, marker parameters of kidney damage in soy isoflavones pretreatment groups shows that antioxidants of soy is effective in improving kidney function.

\section{Conclusions}

The results of our study showed that the soy flour can play a role in the prevention of risk of developing high blood cholesterol and a significant decrease in the concentration of total lipid, triglyceride, total cholesterol, lowdensity lipoprotein, risk factor. Along with a marked increase in the concentration of high-density lipoprotein, in addition to a marked improvement in kidney function of rats fed a high cholesterol diet supplemented with raw and processed soybean flour compared to rats fed on HCD only.

\section{References}

Abdulazeez M (2011). Effect of Peristrophebicalyculataon lipid profile of P-407 induced hyperlipidemic Wistar rats. J Med Plants Res 5(4):490-494.

Abu-Tarboush HM (1998). Irradiation inactivation of some antinutritional factors in plant seeds. J Agric Food Chem 46:2698-2702.

Aleisa AM, Abuohashish HM, Ahmed MM, Al-Rejaie SS, Alkhamees OA, Alroujayee AS (2013). Ameliorative effects of rutin and ascorbic acid combination on hypercholesterolemia-induced hepatotoxicity in female rats. African J Pharma and Pharmacol 7(6):280-288.

Alonso R, Aguirre A, Marzo F (2000a). Effect of extrusion and traditional processing methods on antinutritents and in vitro digestibility of protein and starch in faba and kidney beans. Food Chem 68:159-165.

Alonso R, Grant G, Dewey P, Marzo F (2000b). Nutritional assessment in vitro and in vitro of raw and extruded peas (Pisum sativum L.). J Agric Food Chem 68:2286-2290.

Augusti PR, Ruviaro AR, Quatrin A, Somacal S, Conterato GMM, Vicentini JT, Duarte MMF, Emanuelli T (2012). Imbalance in superoxide dismutase/thioredoxin reductase activities in hypercholesterolemic subjects: relationship with lowdensity lipoprotein oxidation. Lipids in Health and Disease 11:79.

Barbana C, Boucher AC, Boye JI (2010). In vitro binding of bile salts by lentil flours, lentil protein concentrates and lentil protein hydrolysates. Food Res Int 44:174-180.

Baum JA, Teng H, Erdman JW, Weigel RM, Klein BP, Persky VW, Freels S, Surya P, Bakhit RM, Ramos E, Shay NF, Potter SM (1998). Long-term intake of soy protein improves blood lipid profiles and increases mononuclear cell low-density lipoprotein receptor messenger RNA in hypercholesterolemic, postmenopausal women. Am J Clin Nut 68(3):545-551.

Burns RE (1971). Method for estimation of tannin in grain sorghum. Agro J 63:511-512. 
Crouch SR, Batton CJ (1977). Urease-colorimetric method. Anal Chem 49:464-469.

Dixit AK, Vineet Kumar, Rani A, Manjaya JGC, Bhatnagar D (2011). Effect of gamma irradiation on lipoxygenases, trypsin inhibitor, raffinose family oligosaccharides and nutritional factors of different seed coatcolored soybean (Glycine max L.). Radiat Phys Chem 80: 597-603.

El-hady EA, Habiba RA (2003). Effect of soaking and extrusion conditions on antinutrients and protein digestibility of legume seeds. Lebensm Wisse Technol 36:285-293.

Fassati P, Prencipe L (1982). Determination of serum triglycerides. Clin Chem 19:1350.

Feng LJ, Yu CH, Ying KJ, Hua J, Dai XY (2011). Hypolipidemic and antioxidant effects of total flavonoids of Perilla Frutescens leaves in hyperlipidemia rats induced by high-fat diet. Food Res Int 44:404-409.

Frias J, Giacomino S, Penas E, Pellegrino N, Ferreyra V, Apro N, Carrion MO, Vidal-Valverde C (2011). Assessment of the nutritional quality of raw and extruded Pisum sativum L. var. laguna seeds. Lwt-Food Sci Technol 44(5):1303-1308.

Friedewald WT, Levy RI, Fredrickson DS (1972). Estimation of the concentration of low-density lipoprotein cholesterol in plasma, without use of the preparative ultracentrifuge. Clin Chem 18(6):499-502.

Giorgio JD (1974). Determination of plasma creatinine. In "Clinical Chemistry- Principles and Techniques (Henry et al., Eds.). Harper and Row, Hagerstown, p. 503-557.

Gu C, Pan H, Sun Z, Qin G (2010). Effect of Soybean Variety on Anti-Nutritional Factors Content, and Growth Performance and Nutrients Metabolism in Rat. Int J Mol Sci 11:1048-1056.

Hamerstrand GE, Black LT, Glover JD (1981). Trypsin inhibitors in soy products: modification of the standard analytical procedure. Cereal Chem 58:42-45.

Khan N, Sultana S (2004). Abrogation of potassium bromateinduced renal oxidative stress and subsequent cell proliferation response by soy isoflavones in Wistar Rats Toxicol 201:173-184.

Lee J, Hyung-Sook C, Dae-Young K, Joon-Yong C, Jae-Soon C, Han-Kyung L, Nak-Hun S, Kyu KW (2012). Combined effects of exercise and soy isoflavone diet on paraoxonase, nitric oxide and aortic apoptosis in ovariectomized rats. Appetite 58(2):462-469.

Llaneza P, González C, Fernandez-Iňarrea J, Alonso A, Diaz F, Arnott I, Ferrer-Barriendos J (2011). Soy isoflavones, diet and physical exercise modify serum cytokines in healthy obese postmenopausal women. Phytomedicine 18:245-250.

Lopez-Virella MF, Stone PG, Colwell JA (1977). Serum hight density lipoprotein in diabetic patient. Clin Chem 23(5):882-884.

Manzoni C, Duranti M, Eberini I, Scharnag H, Marz W, Castiglion S, Lovati MR (2003). Subcellular localization of soybean $7 \mathrm{~S}$ globulin in HepG2 cells and LDL receptor up- regulation by its alpha' constituent subunit. J Nut 133:21492155.

McLaughlin WL, Wenxia Cohen Jia H, Humphreys JC (1985). Response of radiochromic film dosimeter gamma rays in different atmosphere. Radiat Phys Chem 25:793.

Musa HAA, Ahmed EE, Osman GAM, Ali HA, Ludwig-Müller J (2010). Microbial load and phytochemicals stability of camel hay (Cymbopogon schoenanthus $\mathrm{L}$ ) leaves as affected by gamma irradiation. Agric Biol J N Am 1(4):662-670.

Olorunnisola OS, Bradley G, Afolayan AJ (2012). Anti-hyperlipidemic and biochemical effect of extract of Tulbaghia violacea rhizomes on high cholesterol diet fed rats. African J Biotechnol 11(70):13498-13505.

Pedraza CJ, Barrera D, Hernández-Pando R, Medina-Campos ON, Cruz C, Murguía F, Juárez-Nicolás C, Correa-Rotter R, Torres N, Tovar AR (2004). Soy protein diet ameliorates renal nitrotyrosine formation and chronic nephropathy induced by puromycin aminonucleoside. Life Sci 74:987-999.

Rettberg JR, Hamilton RT, Mao Z, To JB, Zhao L, Appt SE, Register TC, Kaplan JR, Brinton RD (2011). The effect of dietary soy isoflavones before and after ovariectomy on hippocampal protein markers of mitochondrial bioenergetics and antioxidant activity in female monkeys. Brain Res 1379:23-33.

Richmond W (1973). Determination of serum cholesterol. Clin Chem 28:2077.

Rossi EA (2000). Desenvolvimento e avaliação biológica do potencial hipocolesterolêmico de um novo produto probiótico de soja. Araraquara, Brazil: Universidade Estadual Paulista "Júlio de Mesquita Filho".

SPSS (1998). Statistical Package for Social Science. Computer Software, Ver. 10. SPSS Company, London, UK.

Townsend KL, Lorenzi MM, Widmaier EP (2008). High-fat diet-induced changes in body mass and hypothalamic gene expression in wild-type and leptindeficient mice. Endocrine 33:176-188.

Tresina PS, Mohan VR (2012). Physico-chemical and antinutritional attributes of gamma irradiated Vigna unguiculata (L.) Walp. subsp. unguiculata seeds. Int Food Res J 19(2):639646.

Wijeratne WB, Nelson AI (1993). Principles and application of dry extrusion. In: Soybean Processing for Food Uses. International Soy bean Program, INT, Soy, p. 33-86 Ed. Tanteeratarm, K, College of Agri-culture University of Illinois at Urbana Champaign, USA.

Yang D, Lin S, Yang D, Wei L, Shang W (2012). Effects of shortand long-term hypercholesterolemia on contrast-induced acute kidney injury. Am J Nephrol 35(1):80-89.

Young DS (1990). Effects of drugs on clinical laboratory tests. Third Edition 3:6-12.

Zollner N, Kirsch K (1962). Colorimetric method for determination of total lipids. Z Ges Exp Med 135:545 -561. 